\title{
A Study on the Usage Intention of Japanese Learning Mobile Applications
}

\author{
https://doi.org/10.3991/ijet.v16i17.24235 \\ Duen-Huang Huang ${ }^{1}$, Hao-En Chueh $\left.{ }^{2}{ }^{\bowtie}\right)$, Huai-Te Huang ${ }^{3}$, Yueh-Ting Tzou ${ }^{4}$, \\ Chang-Yi Kao ${ }^{5}$ \\ ${ }^{1}$ Chaoyang University of Technology, Taichung City, Taiwan \\ ${ }^{2}$ Chung Yuan Christian University, Taoyuan City, Taiwan \\ ${ }^{3}$ National Taiwan Normal University, Taipei City, Taiwan \\ ${ }^{4}$ National Yunlin University of Science and Technology, Yunlin County, Taiwan \\ ${ }^{5}$ Soochow University, Taipei City, Taiwan \\ hechueh@cycu.edu.tw
}

\begin{abstract}
Mobile applications change living habits and social style and provide an alternative learning channel for foreign languages. The use of applications overcomes limitations of time and space, thus enhancing the effectiveness of foreign language learning. In Taiwan, from the university students learning a foreign language, most part is learning English, followed by Japanese. Many scholars have conducted studies on issues related to English learning applications, but few have studied Japanese learning applications. Therefore, the main purpose of this study is to investigate the factors that influence learners to use Japanese learning applications. An online questionnaire survey was conducted from February 21 to March 2, 2021, in the Japanese language group of the Department of Applied Foreign Languages at a university in northern Taiwan. From the 127 valid forms collected, 40 respondents indicated they have not used Japanese learning applications. Thus, the remaining 87 answers were analyzed using the statistical software IBM SPSS Statistics 20. The results showed that among all variables, the mean score of "perceived ease of use" was the highest and that of "behavioral intention" was the lowest. Empirical analysis revealed that "perceived usefulness," "facilitating conditions," and "social influence" were the key factors that influenced the "behavioral intention" of learners. The findings can provide design guidelines for Japanese learning application developers and serve as a reference for educators to promote the use of Japanese learning applications.
\end{abstract}

Keywords-technology acceptance model, mobile devices, apps, Japanese learning

\section{Introduction}

Information technology (IT) is considered an important tool in language learning processes $[1,2,3]$, and many teachers consider the use of IT as a crucial factor in the quality of language education. According to the study of Bull and Ma [4], the use of IT can provide language learners with more access to learning resources. Harmer [5] and 
Gençlter [6] also suggest that teachers should encourage learners to use IT to find appropriate learning resources for more effective language learning. Gilakjani [7] also believes that the application of IT to language teaching can lead to a more diverse approach. In addition, the visual and auditory perception of language learning can be met with the help of IT. IT allows learners to adjust their learning process, such that they can access and learn many language resources that teachers cannot provide in the classroom $[7,8]$.

Commonly used IT in the language learning process are corpora, online videos, language learning websites, social networking sites, and smart tutoring systems. Corpora are often recognized as powerful technologies in language learning because of their rich dictionary resources [9]. Learning methods using corpus search are popular, and writing and vocabulary learning are particularly well suited for corpus learning [10, 11]. Language learners can also watch online videos (video files on the Internet) related to language learning [12]. Watching movies or TV series in a foreign language, even if they are not specifically related to language learning, is very helpful [13]. Digital resources on language learning websites have been recognized by many language learners as a major source of resources [14], which can be accessed by smartphones or other mobile devices.

Social network sites are also popular language learning platforms in which language learners can create a virtual identity [15] to communicate with other learners such as to learn the target language or culture $[16,17]$. The smart tutoring system is a personalized language learning system [18] that can record specific learning behaviors and provide learning materials and resources based on learners' learning status to improve outcomes.

In addition to the abovementioned applications of IT, language learning through mobile applications (apps) is currently the most popular manner of language learning and will be the mainstream in language learning in the future [19]. Many language learning apps are available in the app store of iOS and Android systems, such as Duolingo, Drops, LingQ, Memrise, and Busuu. These language learning apps mostly provide different languages for learning, and the most common foreign language for learners in Taiwan is English, followed by Japanese. The studies on language learning apps focus on issues regarding English learning, but rarely address Japanese learning. Among the issues about language learning using apps, the key factors that influence learners' usage intention is considerably relevant, which is the focus of this study. The second section will introduce studies on the usage intention in mobile learning; the third section will describe the methodology of this study; the fourth section provides results and discussion; and the fifth section presents conclusions and recommendations.

\section{$2 \quad$ Literature review}

The technology acceptance model (TAM) is the most commonly used theory in the study of behavioral intention of IT or information systems. The TAM was proposed by Davis et al. in 1989 [20]. Based on Fishbein and Ajzen's theory of reasoned action (TRA) [21], Davis et al. proposed a model to explain and predict users' attitudes and 
usage intentions (UI) toward an information system, aiming to illustrate the relevant factors that influence users' adoption of an information system. It is necessary to first explore the reasons why users accept or reject the information system such as to predict and explain their behavior. The TAM is a simplified version of TRA, which focuses on explanations for behaviors associated with the adoption of IT and the analysis of the factors that influence the adoption of IT. In the TAM, perceived usefulness (PU) and perceived ease of use (PEOU) are considered the two main factors that influence the acceptance of information systems. These two factors first influence users' attitudes toward the information system and then influence UI and actual usage behavior. The TAM is shown in Figure 1.

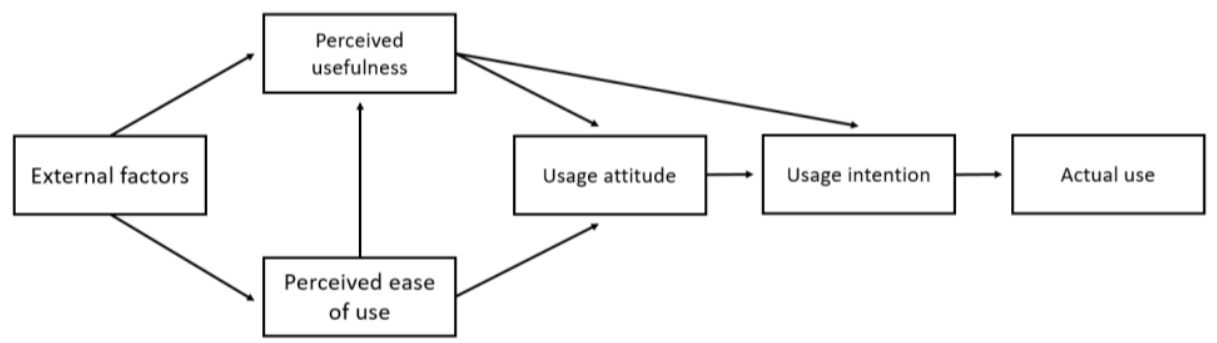

Fig. 1. Technology acceptance model

Many studies have used the TAM or its extended models to examine the factors that influence the application of IT in the learning domain.

In the study of Park et al. [22], TAM was also used to examine the factors that influence the use of mobile learning among Korean university students. This study was conducted with 288 Korean university students to examine the effects of PU, PEOU, selfefficacy, major relevance, system accessibility, and subjective norm on behavioral intention. The results confirmed that system accessibility and subjective norm had a significant effect on the behavioral intention of university students using mobile learning.

In the study of Chung et al. [23], the factors related to behavioral intention that influenced the use of mobile English vocabulary learning resources among 84 Englishas-a-foreign-language university students in Taiwan were evaluated. PU, PEOU, selfefficacy, and compatibility were identified as major factors that may affect UI.

In the study of Chung et al. [24], the continuous intention of 250 Chinese learners to use smartphone apps for learning was studied. The results showed that performance expectancy, social influence (SI), and facilitating conditions (FC) had a positive effect on Chinese learners' behavioral intention of using smartphone learning apps.

In [25], a study was conducted on the factors that may influence the use of mobile technology for learning among medical students in Portugal. The results proved that SI and reliability of recommendation of the technology were the key factors affecting the UI of mobile learning.

In the study of Hao et al. [26], the factors that influenced the use of mobile learning among 292 Chinese university students were examined. The possible factors suggested in the study were PU, PEOU, perceived facilitation, innovativeness, image, and subjective norm. The results indicated that PU, PEOU, perceived facilitation, and image had 
a significant effect on university students' behavioral intention of using mobile learning.

In the study of Israel and Velu [27], the unified theory of acceptance and use of technology model was used to investigate the key factors influencing the behavioral intention to adopt mobile learning among Indian university students. This study was conducted among 116 Indian university students to examine the effect of performance expectancy, effort expectancy, SI, and FC on behavioral intention. The results suggested that performance expectancy and SI had a significant effect on university students' behavioral intention of using mobile learning.

\section{Research method}

\subsection{Research framework and hypotheses}

Based on the above literature review, we identified the following variables that may affect language learning with mobile apps: PU, PEOU, FC, and SI. Therefore, the research framework developed in this study is shown in Figure 2:

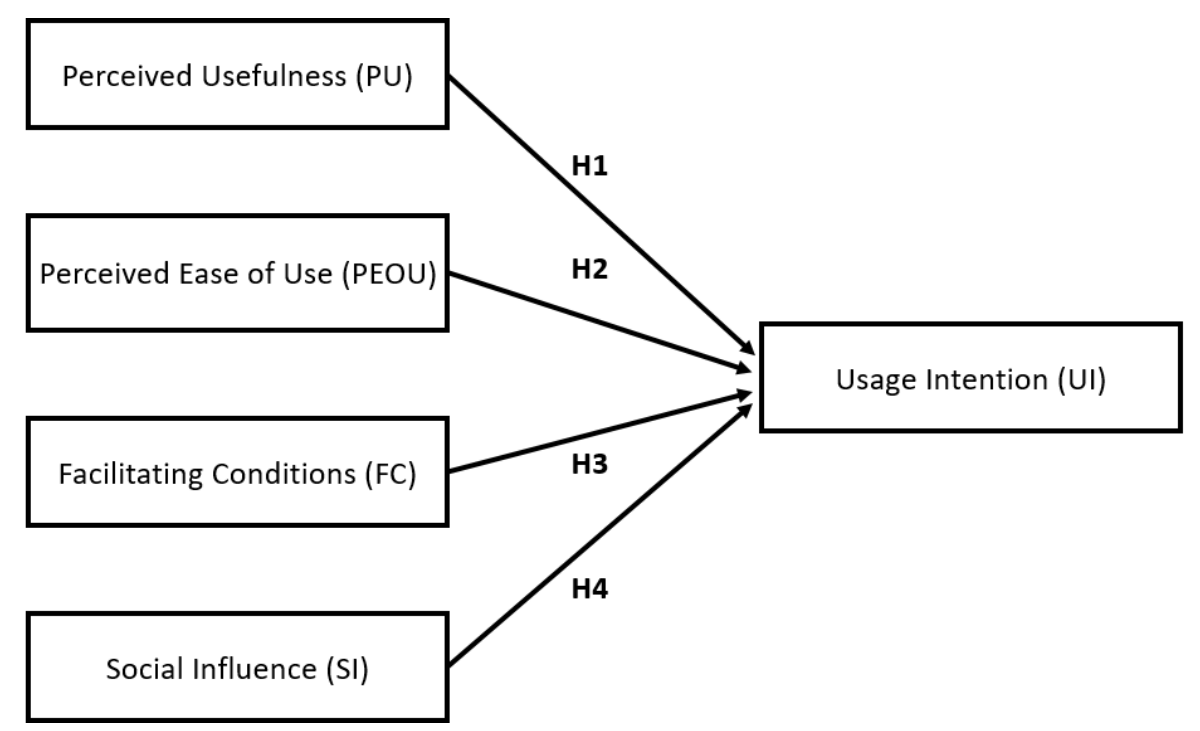

Fig. 2. Research framework

The operational definitions of each research variable are as follows:

- PU: Learners perceive that it is helpful to use Japanese learning apps.

- PEOU: Learners perceive that it is easy to use Japanese learning apps.

- FC: Learners have the necessary knowledge and resources to use Japanese learning apps. 
- SI: Learners believe that the majority of Japanese language learners agree with and use Japanese learning apps.

- UI: Learners are inclined to use Japanese learning apps.

On the basis of the above research framework and the operational definition of the research variables, we formulated the following four hypotheses.

- Hypothesis 1 (H1): PU has a positive effect on the UI of Japanese learning apps.

- Hypothesis 2 (H2): PEOU has a positive effect on the UI of Japanese learning apps.

- Hypothesis 3 (H3): FC has a positive effect on the UI of Japanese learning apps.

- Hypothesis 4 (H4): SI has a positive effect on the UI of Japanese learning apps.

\subsection{Questionnaire design and data collection}

The questionnaire used to collect data was composed of six parts. The first part was related to basic information, which included: (1) gender; (2) age; (3) years of Japanese learning; (4) mobile devices and (5) mobile operating systems used for installing Japanese learning apps. The second to sixth parts were related to the five research variables (PU, PEOU, FC, SI, and UI). The questionnaire was designed using a five-point Likert scale to measure the strength of each question, with "strongly disagree" to "strongly agree" as the answers and numbers 1 to 5 as options. Table 1 shows details of the questionnaire items.

Table 1. Research variables and questionnaire items

\begin{tabular}{|c|c|c|}
\hline $\begin{array}{l}\text { Research } \\
\text { variable }\end{array}$ & Questionnaire items & References \\
\hline \multirow{3}{*}{ PU } & I think it is useful to use a Japanese learning app to learn Japanese. & \multirow{3}{*}[24]{} \\
\hline & $\begin{array}{l}\text { I think using a Japanese learning app can improve the efficiency of learning Jap- } \\
\text { anese. }\end{array}$ & \\
\hline & I think it is useful to use a Japanese learning app to learn Japanese quickly. & \\
\hline \multirow{3}{*}{ PEOU } & I think Japanese learning apps are mostly easy to use. & \multirow{3}{*}[23]{$[25]$} \\
\hline & $\begin{array}{l}\text { I think the interface and function menus of Japanese learning apps are mostly } \\
\text { clear and easy to understand. }\end{array}$ & \\
\hline & I think it is easy for me to learn Japanese with Japanese learning apps. & \\
\hline \multirow{3}{*}{$\mathrm{FC}$} & I have the necessary knowledge to learn Japanese with a Japanese learning app. & \multirow{3}{*}[24]{$[27]$} \\
\hline & I have the necessary resources to learn Japanese with a Japanese learning app. & \\
\hline & $\begin{array}{l}\text { I know how to ask for help when I have problems learning Japanese with a Japa- } \\
\text { nese learning app. }\end{array}$ & \\
\hline \multirow{3}{*}{ SI } & I think my teachers are supportive of the use of Japanese learning apps. & \multirow{3}{*}[25]{$[27]$} \\
\hline & I think my classmates use a Japanese learning app to learn Japanese. & \\
\hline & I think people who are learning Japanese use a Japanese learning app. & \\
\hline \multirow{3}{*}{ UI } & I would like to continue to use the Japanese learning app to learn Japanese. & \multirow{3}{*}{ [23] } \\
\hline & I would recommend a Japanese learning app to my friends and family. & \\
\hline & $\begin{array}{l}\text { I would recommend a Japanese learning app to people in online communities } \\
\text { who want to learn Japanese. }\end{array}$ & \\
\hline
\end{tabular}


In this study, an online questionnaire survey was conducted from February 21 to March 2, 2021, in the Japanese language group of the Department of Applied Foreign Languages at a university in northern Taiwan. A total of 127 valid forms were collected, from which 40 respondents indicated they have not used Japanese learning apps. Therefore, only the remaining 87 forms were analyzed using the statistical software IBM SPSS Statistics 20.

\subsection{Statistical analysis}

Correlation and regression analyses were used to investigate the relationship between the five main variables.

Correlation analysis was primarily used to investigate the linear correlation between two continuous variables $(\mathrm{X}, \mathrm{Y})$. If the correlation coefficient between two variables is absolutely large, it suggests that the degree of mutual covariation is high. In general, $Y$ increases with $\mathrm{X}$ if the correlation between the two variables is positive; conversely, $\mathrm{Y}$ decreases when $X$ increases if the correlation between the two variables is negative. The correlation coefficient between variables obtained from the correlation analysis ranges between 1 and -1: correlation coefficient $=0$ means irrelevant; correlation coefficient $>0$ means positive correlation; correlation coefficient $<0$ means negative correlation. Absolute value of correlation coefficient: $<0.3$, indicates low correlation; between 0.3 and 0.7 , indicates moderate correlation; $>0.7$, indicates high correlation.

Regression analysis is a tool to analyze the relationship between variables. It explores the linear relationship between independent $(\mathrm{x})$ and dependent variables $(\mathrm{y})$, and through the establishment of regression models, the researcher can infer and predict the variables of interest (y). Regression analysis can be divided into simple and multiple regression. Simple regression is used to investigate the relationship between one dependent variable and one independent variable, whereas multiple regression is used to examine the relationship between one dependent variable and multiple independent variables. In this study, multiple regression analysis was used to explore the influence of the four independent variables (PU, PEOU, FC, and SI) on the dependent variable (UI).

\section{$4 \quad$ Results and discussion}

\subsection{Results of descriptive statistics}

The statistical analysis results of the basic data of the questionnaire are shown in Table 2.

According to the statistical results in Table 2, in terms of gender, a higher proportion of respondents was female: $80.5 \%$ were females and $19.5 \%$ were males. As for the age, $77.0 \%$ were aged 16-20 and 23.0\% were aged 21-25. Regarding years of Japanese learning, most part was studying for 3 (inclusive) to 4 years $(31.0 \%)$, followed by 4 years (inclusive) or more $(28,7 \%), 1$ (inclusive) to 2 years $(14.9 \%), 2$ (inclusive) to 3 
years $(13.8 \%)$, and less than 1 year $(11.5 \%)$. Regarding mobile devices used for installing Japanese learning apps, $2.3 \%$ used tablets and $97.7 \%$ used smartphones. Concerning mobile operating systems used for installing Japanese learning apps, iOS represented 58.6\% and Android, $41.4 \%$.

Table 2. Basic data $(\mathrm{N}=87)$

\begin{tabular}{|l|c|c|c|}
\hline \multicolumn{1}{|c|}{ Item } & Option & Frequency & Percentage \\
\hline \multirow{3}{*}{ Gender } & Male & 17 & $19.5 \%$ \\
\hline \multirow{4}{*}{ Age } & Female & 70 & $80.5 \%$ \\
\hline \multirow{3}{*}{ Years of Japanese learning } & $16-20$ years & 67 & $77.0 \%$ \\
\cline { 2 - 4 } & $21-25$ years & 20 & $23.0 \%$ \\
\cline { 2 - 4 } & Less than 1 year & 10 & $11.5 \%$ \\
\cline { 2 - 4 } & 1 (inclusive)-2 years & 13 & $14.9 \%$ \\
\cline { 2 - 4 } & 2 (inclusive)-3 years & 12 & $13.8 \%$ \\
\cline { 2 - 4 } & 3 (inclusive)-4 years & 27 & $31.0 \%$ \\
\cline { 2 - 4 } & 4 years (inclusive) or more & 25 & $28.7 \%$ \\
\hline \multirow{3}{*}{\begin{tabular}{l} 
Mobile devices used for installing \\
\cline { 2 - 4 }
\end{tabular}} & Tablet & 2 & $2.3 \%$ \\
\hline \multirow{2}{*}{$\begin{array}{l}\text { Mobile operating systems used for } \\
\text { installing Japanese learning apps }\end{array}$} & Smartphone & 85 & $97.7 \%$ \\
\cline { 2 - 4 } & iOS & 36 & $58.6 \%$ \\
\hline
\end{tabular}

The Cronbach's $\alpha$ value of the overall questionnaire was 0.966 , which was higher than 0.8 . The Cronbach's $\alpha$ values of all variables were also higher than 0.8 , indicating that the questionnaire had high internal consistency and good reliability, as shown in Table 3.

Table 3. Reliability analysis $(\mathrm{N}=87)$

\begin{tabular}{|l|c|c|c|c|c|c|}
\hline Research variable & PU & PEOU & CF & SI & UI & Total \\
\hline Cronbach's $\alpha$ & 0.869 & 0.890 & 0.944 & 0.854 & 0.933 & 0.966 \\
\hline
\end{tabular}

The mean and standard deviation of each questionnaire item are shown in Table 4.

The highest average score was obtained for the dimension of PEOU, indicating that the current interface and operation process of Japanese learning apps are easy to use for average Japanese learners. The lowest average score was for the dimension of UI, indicating that learners who had used Japanese learning apps before were not inclined to continue using them.

In addition, the item with the highest average score among all items was "I think the interface and function menus of Japanese learning apps are mostly clear and easy to understand." This suggests that if the interface and function menus of Japanese learning apps are designed to be clear and easy to understand, learners find them easy to use. The item with the lowest score was "I think my classmates use a Japanese learning app to learn Japanese," implying that most Japanese learners did not believe that their peers were using Japanese learning apps to learn Japanese. 
Table 4. Statistics on questionnaire items $(\mathrm{N}=87)$

\begin{tabular}{|c|c|c|c|}
\hline Research variable & Questionnaire items & Mean & S.D. \\
\hline \multirow{3}{*}{ PU } & I think it is useful to use a Japanese learning app to learn Japanese. & 3.94 & 0.81 \\
\hline & $\begin{array}{l}\text { I think using a Japanese learning app can improve the efficiency of } \\
\text { learning Japanese. }\end{array}$ & 3.86 & 0.93 \\
\hline & $\begin{array}{l}\text { I think it is useful to use a Japanese learning app to learn Japanese } \\
\text { quickly. }\end{array}$ & 4.01 & 0.88 \\
\hline \multirow{3}{*}{ PEOU } & I think Japanese learning apps are mostly easy to use. & 3.89 & 0.98 \\
\hline & $\begin{array}{l}\text { I think the interface and function menus of Japanese learning apps } \\
\text { are mostly clear and easy to understand. }\end{array}$ & 4.07 & 0.89 \\
\hline & $\begin{array}{l}\text { I think it is easy for me to learn Japanese with Japanese learning } \\
\text { apps. }\end{array}$ & 4.05 & 0.87 \\
\hline \multirow{3}{*}{$\mathrm{FC}$} & $\begin{array}{l}\text { I have the necessary knowledge to learn Japanese with a Japanese } \\
\text { learning app. }\end{array}$ & 3.99 & 0.91 \\
\hline & $\begin{array}{l}\text { I have the necessary resources to learn Japanese with a Japanese } \\
\text { learning app. }\end{array}$ & 3.98 & 0.96 \\
\hline & $\begin{array}{l}\text { I know how to ask for help when I have problems learning Japanese } \\
\text { with a Japanese learning app. }\end{array}$ & 3.85 & 0.96 \\
\hline \multirow{3}{*}{ SI } & $\begin{array}{l}\text { I think my teachers are supportive of the use of Japanese learning } \\
\text { apps. }\end{array}$ & 3.99 & 0.84 \\
\hline & $\begin{array}{l}\text { I think my classmates use a Japanese learning app to learn Japa- } \\
\text { nese. }\end{array}$ & 3.74 & 1.05 \\
\hline & $\begin{array}{l}\text { I think people who are learning Japanese use a Japanese learning } \\
\text { app. }\end{array}$ & 4.00 & 0.95 \\
\hline \multirow{3}{*}{ UI } & $\begin{array}{l}\text { I would like to continue to use the Japanese learning app to learn } \\
\text { Japanese. }\end{array}$ & 3.85 & 0.92 \\
\hline & $\begin{array}{l}\text { I would recommend a Japanese learning app to my friends and fam- } \\
\text { ily. }\end{array}$ & 3.77 & 0.97 \\
\hline & $\begin{array}{l}\text { I would recommend a Japanese learning app to people in online } \\
\text { communities who want to learn Japanese. }\end{array}$ & 3.80 & 0.90 \\
\hline
\end{tabular}

\subsection{Results of empirical analysis}

The results of correlation analysis between variables are shown in Table 5.

Table 5. Correlation analysis

\begin{tabular}{|l|l|l|l|l|l|}
\hline \multicolumn{1}{|c|}{ Research variable } & \multicolumn{1}{c|}{ PU } & \multicolumn{1}{c|}{ PEOU } & \multicolumn{1}{c|}{ FC } & \multicolumn{1}{c|}{ SI } & UI \\
\hline PU & 1 & & & & \\
\hline PEOU & $0.704 * * *$ & 1 & & & \\
\hline FC & $0.713 * * *$ & $0.729 * * *$ & 1 & & \\
\hline SI & $0.629 * * *$ & $0.618 * * *$ & $0.687 * * *$ & 1 & \\
\hline UI & $0.721 * * *$ & $0.684 * * *$ & $0.774 * * *$ & $0.819 * * *$ & 1 \\
\hline
\end{tabular}

Note: *** indicates $\mathrm{P}<0.001$; ** indicates $\mathrm{P}<0.01$; * indicates $\mathrm{P}<0.05$.

As shown by correlation analysis results in Table 5, the correlation coefficients between all variables were statistically significant, and the highest correlation coefficient was 0.819 between SI and UI. Notably, the correlation coefficients between SI and PU, 
PEOU, or FC were all low. The correlation coefficient between SI and PEOU was the lowest at 0.618 , indicating that there was no high correlation between SI and other variables except for UI.

Table 6 shows the regression analysis results between UI and variables such as PU, PEOU, FC, and SI. Adjusted $\mathrm{R}^{2}$ is 0.765 , and F-value is 70.841 .

Table 6. Regression analysis

\begin{tabular}{|l|l|l|l|}
\hline \multicolumn{1}{|c|}{ Research variable } & \multicolumn{1}{c|}{ Standardized Coefficient } & \multicolumn{1}{c|}{ t-value } & \multicolumn{1}{c|}{ P-value } \\
\hline PU & 0.185 & 2.244 & $0.028^{*}$ \\
\hline PEOU & 0.063 & 0.747 & 0.457 \\
\hline FC & 0.266 & 2.977 & $0.004^{* *}$ \\
\hline SI & 0.481 & 6.354 & $0.000^{* * *}$ \\
\hline
\end{tabular}

Note: *** indicates $\mathrm{P}<0.001$; ** indicates $\mathrm{P}<0.01$; * indicates $\mathrm{P}<0.05$

From the regression analysis results in Table 6, in addition to PEOU, the three variables of PU, FC, and SI had a statistically significant effect on UI, supporting hypotheses 1,3 , and 4 .

The empirical analysis showed that learners were more inclined to use Japanese learning apps for Japanese learning when they perceived that it would be helpful. Learners are more inclined to use Japanese learning apps for Japanese learning when they have the necessary knowledge and resources to use such apps and when they believe that the majority of Japanese language learners agree with the app and use it for Japanese learning.

\section{Conclusions and recommendations}

This study focused on the key factors that influence learners to use Japanese learning apps to learn Japanese. Due to the rapid development of wireless networks and mobile devices, this issue has recently been widely researched and discussed. However, most studies have highlighted English learning, and few have been conducted on Japanese learning. The best way to learn a language varies. Over the years, considerable research on English language learning has assisted English learning app developers in designing apps for self-learning. In contrast, there is not sufficient research to assist developers with apps that meet the learning needs of Japanese learners. To fill this gap, we reviewed the literature, compiled a list of factors that may influence Japanese language learners to use Japanese learning apps for self-learning, and conducted an empirical study on Japanese language learners.

The results revealed that the interface design and operation process of most Japanese learning apps already meet the needs of general Japanese language learners. Therefore, there is no need for significant improvement in the system interface or operation process. Most Japanese learners did not believe that their peers were using apps to learn Japanese, but the questionnaire data showed that in the 127 valid copies returned, 87 learners $(68.5 \%)$ had used apps to learn Japanese. To address this issue, this study suggests that teachers who want to use Japanese learning apps to assist learners in their 
learning should regularly ask learners if they have used Japanese learning apps during the teaching process, such that learners can know the percentage of other peer learners using Japanese learning apps.

The study also suggested that PU, FC, and SI had a significant positive effect on UI. In response to this finding, this study suggests that teachers who want to use Japanese learning apps to assist learners should first equip learners with the knowledge and resources needed to use such apps. Japanese learning apps should not be used to assist beginners in Japanese learning; rather, they should be used to assist learners after they have a basic knowledge of the language and learn about relevant Japanese learning resources. In addition, teachers should encourage learners to use Japanese learning apps and provide learners with successful examples of using such apps to enhance their UI.

The results of this study can provide some design guidelines for Japanese learning app developers and teaching strategies for teachers who intend to use Japanese learning apps to assist learners.

\section{References}

[1] Becker, H. J. (2000). Findings from the teaching, learning, and computing survey: Is Larry Cuban right? Education Policy Analysis Archives, 8(51).

[2] Murzo, Y., \& Chuvileva, N. (2021). Use of Information Technologies in Developing Foreign Language Competence for Professional Interaction of Undergraduate and Postgraduate Students Specializing in Mineral Resources. International Journal of Emerging Technologies in Learning, 16(3): 144-153. https://doi.org/10.3991/ijet.v16i03.17875

[3] Kolyada, N., Shapovalova, L., Guz, Y., \& Melkonyan, A. (2021). Distance Learning of a Foreign Language - Necessity or Future. International Journal of Emerging Technologies in Learning, 16(4): 167-187. https://doi.org/10.3991/ijet.v16i04.18299

[4] Bull, S., \& Ma, Y. (2001). Raising learner awareness of language learning strategies in situations of limited recourses. Interactive Learning Environments, 9(2): 171-200. https://doi. org/10.1076/ilee.9.2.171.7439

[5] Harmer, J. (2007). The practice of English language teaching. England: Pearson.

[6] Gençlter, B. (2015). How does technology affect language learning process at an early age? Procedia - Social and Behavioral Sciences, 199: 311 - 316. https://doi.org/10.1016/j. sbspro.2015.07.552

[7] Gilakjani, A. (2017). A review of the literature on the integration of technology into the learning and teaching of English language skills. International Journal of English Linguistics, 7(5): 95-106.

[8] Aprianto, E., Purwati, O., \& Anam, S. (2020). Multimedia-Assisted Learning in a Flipped Classroom: A Case Study of Autonomous Learning on EFL University Students. International Journal of Emerging Technologies in Learning, 15(24): 114-127. https://doi.org/10. 3991/ijet.v15i24.14017

[9] Frankenberg-Garcia, A., Lew, R., Roberts, J. C., Rees, G. P., \& Sharma, N. (2019). Developing a writing assistant to help EAP writers with collocations in real time. ReCALL, 31(1): 23-39. https://doi.org/10.1017/s0958344018000150

[10] Li, S. (2017). Using corpora to develop learners' collocational competence. Language Learning \& Technology, 21(3): 153-171.

[11] Ackerley, K. (2017). Effects of corpus-based instruction on phraseology in learner English. Language Learning \& Technology, 21(3): 195-216. 
[12] Arndt, H. L., \& Woore, R. (2018). Vocabulary learning from watching YouTube videos and reading blog posts. Language Learning \& Technology, 22(1): 124-142.

[13] Yeh, H. C. (2018). Exploring the perceived benefits of the process of multimodal video making in developing multiliteracies. Language Learning \& Technology, 22(3): 28-37.

[14] Shen, H., Yuan, Y., \& Ewing, R. (2015). English learning websites and digital resources from the perspective of Chinese university EFL practitioners. ReCALL, 27(2): 156-176. https://doi.org/10.1017/s0958344014000263

[15] Maier, C., Laumer, S., Eckhardt, A., \& Weitzel, T. (2015). Giving too much social support: Social overload on social networking sites. European Journal of Information Systems, 24(5): 447-464. https://doi.org/10.1057/ejis.2014.3

[16] Blattner, G., \& Fiori, M. (2011). Virtual social network communities: An investigation of language learners' development of sociopragmatic awareness and multiliteracy skills. CALICO Journal, 29(1): 24-43. https://doi.org/10.11139/cj.29.1.24-43

[17] Klimanova, L., \& Dembovskaya, S. (2013). L2 identity, discourse, and social networking in Russian. Language Learning \& Technology, 17(1): 69-88.

[18] Malekzadeh, M., Mustafa, M. B., \& Lahsasna, A. (2015). A review of emotion regulation in intelligent tutoring systems. Educational Technology \& Society, 18(4): 435-445.

[19] Elaish, M. M., Shuib, L., Abdul Ghani, N., Yadegaridehkordi, E., \& Alaa, M. (2017). Mobile Learning for English Language Acquisition: Taxonomy, Challenges, and Recommendations. IEEE Access, 5: 19033-19047. https://doi.org/10.1109/access.2017.2749541

[20] Davis, F. D., Bagozzi, R. P., \& Warshaw, P. R. (1989). User acceptance of computer technology: A comparison of two theoretical models. Management Science, 35(8): 982-1003. https://doi.org/10.1287/mnsc.35.8.982

[21] Fishbein, M., \& Ajzen, I. (1975). Belief, Attitude, Intention, and Behavior: An Introduction to Theory and Research. Reading, MA: Addison-Wesley.

[22] Park, S. Y., Nam, M.-W., \& Cha, S.-B. (2012). University students' behavioral intention to use mobile learning: Evaluating the technology acceptance model. British Journal of Educational Technology, 43(4): 92-605. https://doi.org/10.1111/j.1467-8535.2011.01229.x

[23] Chung, H.-H., Chen, S.-C., \& Kuo, M.-H. (2015). A Study of EFL College Students' Acceptance of Mobile Learning. Procedia - Social and Behavioral Sciences, 176: 333-339. https://doi.org/10.1016/j.sbspro.2015.01.479

[24] Feng, Y., Worrachananun, M., \& Lai, I.K. (2015). Students' Preferences and Intention on Using Smartphone Education Applications. 2015 International Symposium on Educational Technology (ISET), July 27-29 2015, Wuhan, China, pp. 109-112. https://doi.org/10.1109/ iset.2015.30

[25] Briz-Ponce, L., Pereira, A., Carvalho, L., Juanes-Méndez, J. A., \& García-Peñalvo, F. J. (2017). Learning with mobile technologies - Students' behavior. Computers in Human Behavior, 72: 612-620. https://doi.org/10.1016/j.chb.2016.05.027

[26] Hao, S., Dennen, V. P., \& Mei, L. (2017). Influential factors for mobile learning acceptance among Chinese users. Educational Technology Research and Development, 65(1): 101-123. https://doi.org/10.1007/s11423-016-9465-2

[27] Israel, D. J., \& Velu, R. (2019). The Partial Test of UTAUT Model to Explain the Influence of Variables on the Intention to Adopt the Mobile Learning in Higher Education. International Journal of Innovative Technology and Exploring Engineering, 8(8): 1076-1082. 


\section{Authors}

Duen-Huang Huang is an associate professor of the Center of Teacher Education at Chaoyang University of Technology, Taichung City, Taiwan. He received his Ph.D. in Industrial Education from National Taiwan Normal University, Taiwan in 2014. His research areas include e-learning, digital transformation, and fuzzy mathematics.

Hao-En Chueh is an assistant professor of the Department of Information Management at Chung Yuan Christian University, Taoyuan City, Taiwan. He received his Ph.D. in Computer Science and Information Engineering from Tamkang University, Taiwan in 2007. His research areas include e-learning, data dining, artificial intelligence, medical informatics.

Huai-Te Huang, a graduate student of Industrial Education at National Taiwan Normal University, is the Principal of Taoyuan Municipal Yung-Feng High School. He has been a Curriculum Supervisor of Senior High School Education in Department of Education, Taoyuan City Government in 2019-2020. He also majored in Guidance and Counseling (B.A.) and History (M.A.).

Yueh-Ting Tzou, a graduate student of Graduate School of Technological and Vocational Education at National Yunlin University of Science and Technology, is the Principal of Taoyuan Municipal Yang Mei Senior High School. His current research interests include educational strategy research, e-learning, scientific and technological education.

Chang-Yi Kao is an assistant professor of the Department of Computer Science \& Information Management, Soochow University, Taipei City, Taiwan. He was a sector manager of Institute for Information Industry, and he is also an industry analyst of Asia Pacific Industrial Association (APIAA). His current research interests include intelligent system, open data, business intelligent, service experience engineering.

Article submitted 2021-05-24. Resubmitted 2021-07-27. Final acceptance 2021-07-27. Final version published as submitted by the authors. 